\title{
Capital Structure Evaluation Model on PPP Power Projects
}

\author{
Liping Wang ${ }^{1}$, Pu Zhang ${ }^{1}$, Yi Liu ${ }^{1}$, Yi Wang ${ }^{2}$ and Hongbing Wang ${ }^{3}$ \\ ${ }^{1}$ North China Electric Power University, Beijing, P. R. China \\ ${ }^{2}$ Power Construction Corporation of China, Kunming Engineering Corporation Limited, Kunming, P. R. China \\ ${ }^{3}$ Huaneng Lancang River Hydropower Inc., Kunming, P. R. China
}

\begin{abstract}
In recent years, more opportunities is provided for Chinese electric power group to participate overseas power projects along with the application of public-private partnership(PPP), and how to evaluate asset structure became to be a crucial for the smooth implementation of these PPP power project. This paper aims to establish an asset structure evaluation model and relative evaluation index system for PPP power project based on TOPSIS model. The case study shows that this model can be effectively applied to the asset structure scheme evaluation process of PPP power project and also can provide important reference for the management and decision making.
\end{abstract}

Keywords-PPP; power project, asset structure; TOPSIS

\section{INTRODUCTION}

As an important part of the national economy, electric power project has a strong public welfare and social feature, while its construction investment is huge, relying solely on the government's financial investment is difficult to bear. In recent years, some countries especially developing countries have opened the energy industry for foreigners which was owned by the states monopoly in the past, and introduce foreign or private capital to participate into the energy and power projects by PPP mode. The increasingly extensive application of PPP mode in the international field of power industry could meet the gap between the government's financial investment and actual capital demands, along with rapid development of the energy and power industry in those countries, more opportunities is provided for Chinese electric power group to participate overseas projects.

It is widely believed that private institutions can provide public products via the PPP model so as to obtain long-term stable investment return; meanwhile, the government departments can realize the effects to transfer risk to the private institutions, solve the constraint due to budget shortfall, improve the overall planning ability of the government, provide public products and services of better quality and shorten the construction time of the project, etc [1-2]. It is noteworthy that the realization of a balanced pattern with benefit sharing for each party will be the key to PPP project due to the complexity of the cooperation model, and its capital structure objects are multi-layered, i.e. realizing the financing purpose and distributing the project risks and benefits [3], therefore, how to establish a reasonable capital structure is crucial for the smooth implementation of PPP project and is also the focus of the researcher.
In empirical practice, the domestic and foreign scholars usually simplify the complex content when studying the influence factors of capital structure, e.g. studying the assetliability ratio, debt capitalization ratio or financing scale and other quantitative factors [4-7]. However, PPP project involves in many public facilities projects with certain quasi-welfare, many participants and complex cooperation models, thus, the capital structure evaluation of PPP project has some differences with that of the conventional project, and related research results can't be used for reference simply[8]. Currently, the capital structure evaluation of PPP project is rarely studied, and most researches are limited to qualitative analysis, which were some useful references for studying the capital structure of PPP project.

Considering the conspicuous multi-player game during the cooperation process of PPP power project, this paper, from the perspective of value balance for the participant, establishes assets structure quantitative evaluation model for PPP power project based on TOPSIS model, improves the "negative sequence" which may occur in TOPSIS model through introducing grey correlation, and solves the uncertain information sequence during the evaluation by introducing distance entropy weight method, which will provide references for capital structure design and decision of future PPP power project

\section{RESEARCH METHOD}

A. Capital Structure Evaluation Index System of PPP Powerct PPP power project is featured by complex cooperation way and many participants, and they have their own interests and goals [9]. From the perspective of private owner, the focus is cash earnings; the focus of the government is social benefit; and the focus of the lender is the credit risk and capital gains of the power project. Therefore, the following models may be used to express the profit maximization of each participant:

a) Profit maximization of private owner - expressed by free cash flow model [10]

b) Profit maximization of the government - expressed by welfare economics model [11].

c) Profit maximization of the lender - expressed by creditor's rights value maximization model [12] 
Thus, the evaluation index system is finally determined as shown in Figure I through index analysis of the above models and in combination with the literature references [3,13-20] and semi-structured interview.

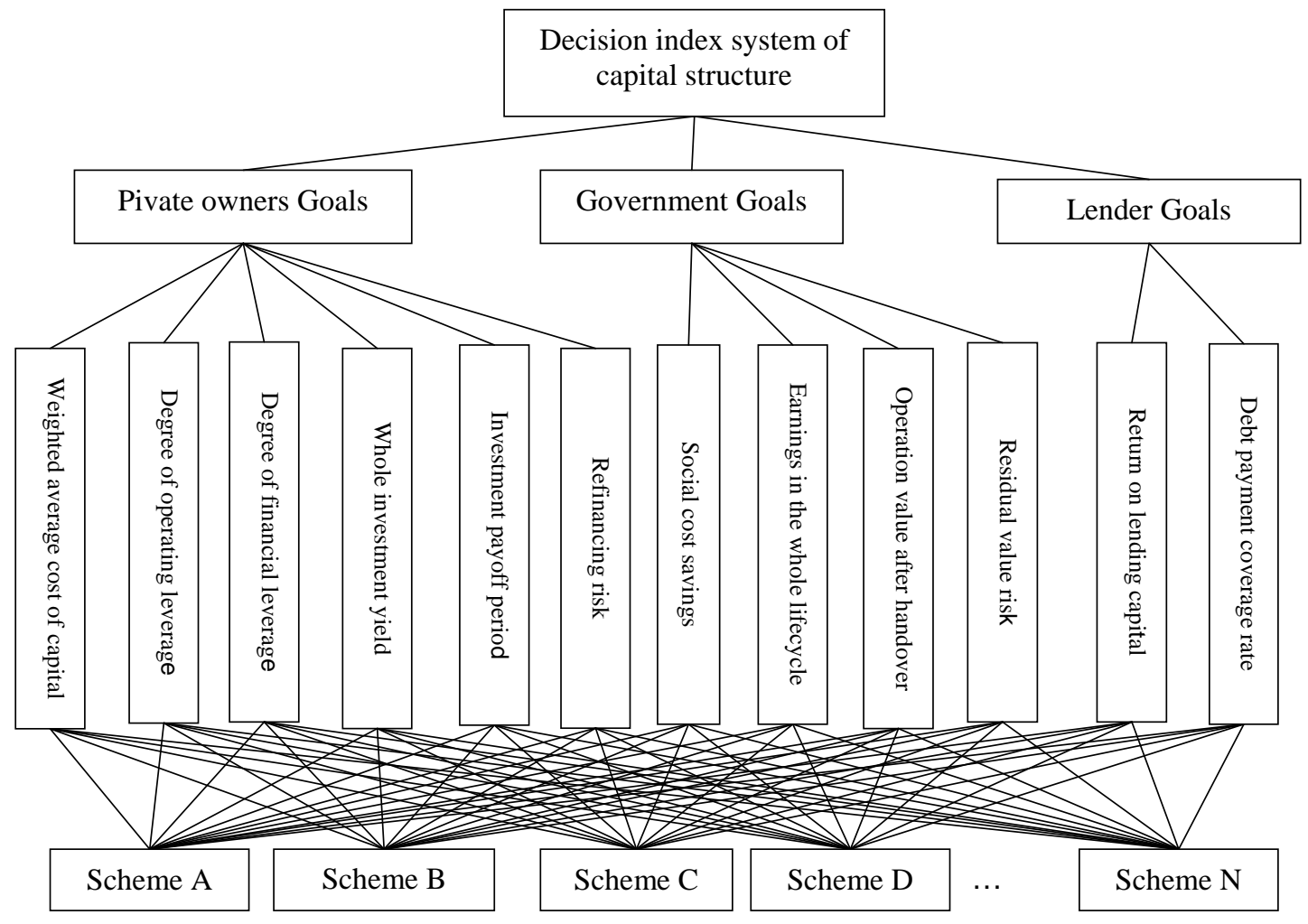

FIGURE I. CAPITAL STRUCTURE EVALUATION INDEX SYSTEM OF PPP POWER PROJECT

\section{B. Methodology}

This method was put forward by Hwang and Yoon [21], and the principle is to sort the evaluation objects based on the Eculid distance to the positive ideal scheme and negative ideal scheme in the multi-objective decision-making problem. The core thought of TOPSIS algorithm is: setting positive ideal point (positive ideal scheme) and negative ideal point (negative ideal scheme), and calculate the Eculid distance of each scheme to the positive and negative ideal points respectively; the scheme that is the closest to the positive ideal point and farthest to the negative ideal point will be deemed as the optimal scheme. At present, TOPSIS, as a relatively perfect common method for solving the fuzzy multi-attribute decision-making problem, is applied in project selection, performance evaluation and other fields.

\section{Model Steps}

1) Establish multi-attribute decision-making matrix: If the scheme set $Q\left(Q_{1}, Q_{2}, \cdots Q_{m}\right)$ is constituted by m alternative schemes, the evaluation set $R\left(R_{1}, R_{2}, \cdots R_{n}\right)$ is constituted by $\mathrm{n}$ decision attributes, and the evaluation index is recorded as $p_{i j}(i=1,2, \cdots, n ; j=1,2, \cdots, m)$, i.e. $\mathrm{P}_{\mathrm{ij}}$ means the $\mathrm{j}$ evaluation index in the i scheme. Then an initial judgment matrix will be established as follows,

$$
P=\left(p_{i j}\right)_{m \times n}=\left[\begin{array}{cccc}
p_{11} & p_{12} & \cdots & p_{1 n} \\
p_{21} & p_{22} & \cdots & p_{2 n} \\
\cdots & \cdots & \cdots & \cdots \\
p_{m 1} & p_{m 2} & \cdots & p_{m n}
\end{array}\right]
$$

Of which, the corresponding evaluating value of the refinancing difficulty and residual value risk in Figure I, expressed by the thought of fuzzy language set, is shown in Table I:

TABLE I. SCORE OF RISK

\begin{tabular}{|l|c|c|c|c|c|}
\hline Score & 0.0-2.0 & 2.0-4.0 & 4.0-6.0 & $\mathbf{6 . 0 - 8 . 0}$ & $\mathbf{8 . 0 - 1 0 . 0}$ \\
\hline Risk & $\begin{array}{c}\text { Very } \\
\text { low }\end{array}$ & Low & Medium & High & $\begin{array}{c}\text { Very } \\
\text { high }\end{array}$ \\
\hline
\end{tabular}
2) Standardize each index: Adopt range method to
perform dimensionless method for the evaluation indexes of different types, establish standardized decision-making matrix $\mathrm{m}_{\mathrm{mn}}=\left(u_{m n}\right)_{m \times n}$, of which, for the efficiency index, there

$$
u_{\mathrm{mn}}=\frac{p_{m n}-\min _{m} p_{m n}}{\max _{m} p_{m n}-\min _{m} p_{m n}}
$$

for the cost index, there 


$$
u_{\mathrm{mn}}=\frac{\max _{m} p_{m n}-p_{m n}}{\max _{m} p_{m n}-\min _{m} p_{m n}}
$$

3) Determine the positive and negative ideal scheme: Set $u_{i}^{+}=\left\{\max u_{i j}\right\}, u_{i}^{-}=\left\{\min u_{i j}\right\}, j \in(1,2, \cdots, n)$, then schemes $u_{i}^{+} 1$ siand $u_{i}^{-}$are the ${ }^{<i}$ positive and negative ideal solution schemes, and,

$$
\begin{aligned}
& u^{+}=\left\{u_{1}^{+}, u_{2}^{+}, \cdots u_{n}^{+}\right\}=\{1,1, \cdots 1\} \\
& u^{-}=\left\{u_{1}^{-}, u_{2}^{-}, \cdots u_{n}^{-}\right\}=\{0,0, \cdots 0\}
\end{aligned}
$$

4) Calculate the Euclid distance ${ }^{d_{j}}$ to ${ }^{u_{i}^{+}}$and $u_{i}^{-}$of each scheme,

$$
d_{i}^{+}=\sqrt{\sum_{j=1}^{m}\left(a_{i j}^{+}-a_{i j}\right)^{2}} \quad \alpha v \delta \delta d_{i}^{-}=\sqrt{\sum_{j=1}^{m}\left(a_{i j}^{-}-a_{i j}\right)^{2}}
$$

5) Calculate the relational coefficient ${ }^{C_{j}}$,

$$
C_{j}=\frac{d_{j}^{-}}{d_{j}^{-}+d_{j}^{+}},(1 \leq j \leq m)
$$

6) Sort the schemes based on the Euclid distance.

\section{CASE STUDY}

\section{A. Project Background}

A wind power PPP project is taken as a simplified example to state the model application process. In this power project, the capital source involved in each scheme is third party financing, and the contract is not changed in the franchise period, thus, the return on whole investment, investment payoff period, social cost savings, earnings in the whole lifecycle and residual value risk index are basically the same. To simplify the calculation process, the above indexes are removed. Table (1) shows the computing result of the rest relevant financial indexes of this alternative.

TABLE II. INDEXES OF FINANCING PLAN

\begin{tabular}{|c|c|c|c|c|}
\hline Index & Scheme 1 & Scheme 2 & Scheme 3 & $\begin{array}{l}\text { Scheme } \\
\mathbf{4}\end{array}$ \\
\hline $\begin{array}{c}\text { Weighted average } \\
\text { cost of capital }\end{array}$ & $9.23 \%$ & $8.92 \%$ & $8.41 \%$ & $7.83 \%$ \\
\hline $\begin{array}{c}\text { Degree of operating } \\
\text { leverage }\end{array}$ & 1.44 & 1.47 & 1.55 & 1.69 \\
\hline $\begin{array}{c}\text { Degree of financial } \\
\text { leverage }\end{array}$ & 1.19 & 1.23 & 1.34 & 1.40 \\
\hline $\begin{array}{c}\text { Refinancing risk } \\
\text { Earnings in the } \\
\text { whole lifecycle(\$) }\end{array}$ & 6835 & 6775 & 6615 & 6560 \\
\hline
\end{tabular}

\begin{tabular}{|c|c|c|c|c|}
\hline $\begin{array}{c}\text { Return on lending } \\
\text { capita }\end{array}$ & 5.11 & 5.16 & 5.18 & 5.21 \\
\hline $\begin{array}{c}\text { Debt payment } \\
\text { coverage rate }\end{array}$ & 17.7 & 17.24 & 16.36 & 15.88 \\
\hline
\end{tabular}

\section{B. Computation Process}

1) Normalize the data based on the formula (1) and (2), and see Table (3) for the results:

TABLE III. STANDARDIZATION RESULTS OF INDEXES

\begin{tabular}{|c|c|c|c|c|}
\hline Index & Scheme 1 & Scheme 2 & Scheme 3 & Scheme 4 \\
\hline $\begin{array}{c}\text { Weighted average } \\
\text { cost of capital }\end{array}$ & 0.00 & 0.12 & 0.32 & 0.55 \\
\hline $\begin{array}{c}\text { Degree of operating } \\
\text { leverage }\end{array}$ & 0.41 & 0.36 & 0.23 & 0.00 \\
\hline $\begin{array}{c}\text { Degree of financial } \\
\text { leverage }\end{array}$ & 0.52 & 0.31 & 0.18 & 0.00 \\
\hline $\begin{array}{c}\text { Refinancing risk } \\
\text { Earnings in the } \\
\text { whole lifecycle }\end{array}$ & 0.54 & 0.30 & 0.16 & 0.00 \\
\hline $\begin{array}{c}\text { Return on lending } \\
\text { capita }\end{array}$ & 0.44 & 0.33 & 0.22 & 0.00 \\
\hline $\begin{array}{c}\text { Debt payment } \\
\text { coverage rate }\end{array}$ & 0.50 & 0.37 & 0.13 & 0.00 \\
\hline
\end{tabular}

TABLE IV. CALCULATE THE EUCLID DISTANCE ${ }^{d_{j}}$ TO $u_{i}^{+}$AND $u_{i}^{-}$OF EACH SCHEME

\begin{tabular}{|c|c|c|c|c|c|c|c|c|}
\hline \multirow{2}{*}{ Index Distance } & \multicolumn{2}{|c|}{ Scheme 1 } & \multicolumn{2}{c|}{ Scheme 2 } & \multicolumn{2}{l|}{ Scheme 3 } & \multicolumn{2}{|c|}{ Scheme 4 } \\
\cline { 2 - 9 } & \multicolumn{2}{|c|}{$u_{i}^{+} / u_{i}^{-}$} & \multicolumn{2}{c|}{$d_{i}^{+} / d_{i}^{-}$} & \multicolumn{2}{c|}{$d_{i}^{+} / d_{i}^{-}$} & \multicolumn{2}{|c|}{$d_{i}^{+} / d_{i}^{-}$} \\
\hline $\begin{array}{c}\text { Weighted } \\
\text { average cost of } \\
\text { capital }\end{array}$ & 0.55 & 0 & 0.43 & 0.12 & 0.23 & 0.32 & 0 & 0.55 \\
\hline $\begin{array}{c}\text { Degree of } \\
\text { operating } \\
\text { leverage }\end{array}$ & 0 & 0.41 & 0.05 & 0.36 & 0.18 & 0.23 & $\begin{array}{c}0.4 \\
1\end{array}$ & 0 \\
\hline $\begin{array}{c}\text { Degree of } \\
\text { financial } \\
\text { leverage }\end{array}$ & 0 & 0.52 & 0.21 & 0.31 & 0.34 & 0.18 & $\begin{array}{c}0.5 \\
2\end{array}$ & 0.21 \\
\hline \begin{tabular}{c} 
Refinancing risk \\
\hline $\begin{array}{c}\text { Earnings in the } \\
\text { whole lifecycle }\end{array}$
\end{tabular} & 0 & 0.54 & 0.24 & 0.3 & 0.38 & 0.16 & $\begin{array}{c}0.5 \\
4\end{array}$ & 0 \\
\hline $\begin{array}{c}\text { Return on } \\
\text { lending capita }\end{array}$ & 0 & 0.44 & 0.11 & 0.33 & 0.22 & 0.22 & $\begin{array}{c}0.4 \\
4\end{array}$ & 0 \\
\hline $\begin{array}{c}\text { Debt payment } \\
\text { coverage rate }\end{array}$ & 0 & 0.5 & 0.13 & 0.37 & 0.37 & 0.13 & 0.5 & 0 \\
\hline
\end{tabular}

2) Calculate the empowerment value of distance entropy to get the weight sets of each index, the result as follows, Euclid distance

\begin{tabular}{|c|c|c|c|c|}
\hline & Scheme 1 & Scheme 2 & Scheme 3 & Scheme 4 \\
\hline Score & 0.6845 & 0.5976 & 0.3926 & 0.3342 \\
\hline
\end{tabular}

3) Therefore, the Sort preferable order as follows,

Scheme1> Scheme2>Scheme 3>Scheme 4

\section{CONCLUSION}

The asset structure of PPP power project affects the balanced pattern of the interests of all parties, thus, the asset structure of PPP power project is directly related to the cost, 
income and risk of the power project, which is also an important part of PPP power project decision and also a complex multi-objective decision process. This paper, from the perspective of the balance between the participants of PPP power project, puts forward a set of evaluation index system based on the profit maximization model for each participant, and conduct capital structure evaluation based on TOPSIS model. As case study shows, this model is accurate and objective, the computation process is simple and convenient, with strong operability, providing new thought for the design and decision of capital structure of PPP power project. The author hopes that the researches in this paper can provide certain experience and reference for the design and decision of capital structure of PPP power project.

\section{REFERENCES}

[1] Li, B., Akintoye, A., Edwards, P.J., et al. Perceptions of positive and negative factors influencing the attractiveness of PPP/PFI procurement for construction projects in the LJK: Findings from a questionnaire survey[J]. Construction and Architecture Management, 2005a, 12(2):125-148.

[2] Akintoye A, Beck M, Hardcastle C. Public-private partnerships: managing risks and opportunities. UK, Blackwell Science, 2003.

[3] Liu, Y. Optimal Capital Structure for Public-Private Partnership Projects' Refinance. Doctor of Philosophy, Tsinghua University, China, 2012

[4] GUO Pengfei, Sun Peiyuan, The Industrial Characteristic of Capital Structure:An EmpiricalStudy on Chinese Listed Companies, Economic Research Journal, 2003 ( 05 ) : 66-73.

[5] Qiao Hengli. Study on the mutiple mode selectrion of infrastructure project investment and financin [D]. Shanghai Jiao Tong University.2009.

[6] Fan Xiaojun, ZHONG Genyuan, Research on the optimal allocation model of Infrastructuren project financing risk [J]. Modern Economic Research.2005(03).

[7] Fan Xiaojun, Zhao Yi, ZHONG, Study on Allocation Proportion of Infrastructure Project Financing Risk [J]. Journal of Industrial Engineering Engineering Management,2007,01:98-101.

[8] Sheng, H. Study on the Capital Structure of PPP/BOT projects. Doctor of Philosophy, Tsinghua University, China, 2013.

[9] Study on Optimal Equity Structure for Special Purpose Vehicle of PPP Projects, Weijian Ren[D] 27-49.

[10] TE Copeland, T Koller, J Murrin, Valuation: Measuring and Managing the Value of Companies, McKinsey and Company, 2000 3rd ed.

[11] Yang H, Meng Q. Highway pricing and capacity choice in a road network under a build-operate-transfer scheme. Transportation Research Part A: Policy and Practice, 2000,34(3): 207-222.

[12] Tiong RLK. Competitive advantage of equity in BOT tender. Journal of Construction Engineering and Management, 1995,121(3): 282-289.

[13] Tang, L.; Shen, Q.; Cheng, E.W.L. A review of studies on PublicPrivate Partnership projects in the construction industry. Int. J. Proj. Manag. 2010, 28, 683-694.

[14] Xu, Y.; Peng, Y.; Qian, Q.K.; Chan, A.P.C. An alternative model to determine the financing structureof PPP-based young graduate apartments in China: A Case Study of Hangzhou. Sustainability 2015, 7,5720-5734.

[15] Chan, A.; Yeung, J.; Yu, C.; Wang, S.; Ke, Y. Empirical study of risk assessment and allocation of public-private partnership projects in China. J. Manag. Eng. 2011, 27, 136-10, DOI: 10.1061/(ASCE)ME.19435479.0000049.

[16] ADB, World Bank, JBIC. Connecting East Asia: A New Framework for Infrastructure. Asian Development Bank, The World Bank, and Japan Bank for International Cooperation. 2005.
[17] World Bank. Private Participation in Infrastructure Database [M]. 2013.

[18] Carlos Pestana Barros. Efficiency analysis of hydroelectric generating plants: a case study forPortugal[J]. Energy Economics, 2008,30:59 75.

[19] LIANG Shu-guang, CUI Jian, YUAN Jian.Relationship between Ownership Structure and Technical Efficiency of Chinese Listed Companies in Electric Power Industry:Based on the Super-Efficiency DEA Model and Panel Model. Journal of Financial Research,2011,4:7886.

[20] Akintoye A, Hardcastle C, Beck M, et al. Achieving best value in private finance initiative project procurement. Construction Management and Economics, 2003,21(Compendex):461-470.

[21] H. Goto, Y. Hasegawa, and M. Tanaka, "Efficient Scheduling Focusing on the Duality of MPL Representatives," Proc. IEEE Symp. Computational Intelligence in Scheduling (SCIS 07), IEEE Press, Dec. 2007, pp. 57-64, doi:10.1109/SCIS.2007.357670. 